\title{
A CORRESPONDENNCIA LUSO-BRASILEIRA: NARRATIVA DE UM TRÂNSITO INTERCULTURAL
}

\author{
POR \\ Clara Sarmento \\ Polytechnic Institute of Oporto
}

INTRODUÇÃO

“A Correspondência Luso-Brasileira: Narrativa de um Trânsito Intercultural” segue as histórias de vida entre Portugal e o Brasil das famílias Pinto da França e Garcez, com especial atenção ao percurso intercultural de Maria Bárbara Garcez Pinto de Madureira, nascida em Penafíel em 1779, e casada com o oficial de origem baiana Luís Paulino Pinto da França. Durante as invasões francesas parte para o Brasil, passando a viver junto da corte, entre o Rio de Janeiro e a Baía, de onde nunca mais regressará. Viúva em 1824, sobre ela recai já há muito a responsabilidade da exploração do engenho açucareiro de Aramaré, que administrará até à morte, em 1851.

Este trânsito intercultural é documentado através das cartas trocadas entre diversos elementos das famílias intervenientes, com especial relevo para as numerosas cartas da autoria de Maria Bárbara, cujo estilo surpreende pela cultura e pela originalidade de expressão numa mulher originária da fidalguia rural portuguesa da segunda metade do século XVIII. Maria Bárbara compõe uma visão participante, lúcida e esclarecida dos dramáticos acontecimentos que rodearam a independência do Brasil, muitas vezes oposta às versões propagadas pelas facções em conflito, não se coibindo de esclarecer e admoestar o marido e seus pares nas cortes em Portugal sobre as realidades do território. Atenta aos assuntos políticos, militares e administrativos, a família torna-se pouco a pouco uma nota residual, referida apenas quando afectada pelas circunstâncias históricas. Maria Bárbara inicia o seu percurso entre culturas como simples espectadoraleitora, tornando-se progressivamente numa comentadora-actora-protagonista-autora na sociedade, na política e na história.

Este caso de estudo ilustra um peculiar percurso de transição identitária intercultural, de uma dama provinciana portuguesa para uma senhora de engenho no Recôncavo Baiano, traduzido numa narrativa epistolar quase sempre simultânea, ou imediatamente consecutiva, a esse percurso. $\mathrm{O}$ processo de tradução intercultural assim narrado, tanto na primeira como na terceira pessoa, permite acompanhar a negociação de uma nova 
identidade, tão híbrida quanto assertiva. O conceito de tradução intercultural aqui utilizado baseia-se no pensamento articulado por Boaventura de Sousa Santos, que defende que a existência de diferenças - tanto espistemológicas como no senso-comum e nas práticas, valores e experiências do quotidiano (ou seja, diferenças culturais) - faz com que a respectiva comparação tenha de ser feita através de procedimentos de busca de proporção e correspondência que, no seu conjunto, constituem o trabalho de tradução. Estes procedimentos permitem aproximações sempre precárias ao desconhecido a partir do conhecido, ao estranho a partir do familiar, ao alheio a partir do próprio O exercício reiterado da tradução revela que os procedimentos desenvolvidos para conhecer outros saberes acabam por ser os mesmos com que cada saber conhece a experiência do mundo em geral (SANTOS, 2008: 29-30). Admitindo a diversidade de narrativas e de expressões de conhecimento situado, patentes na Correspondência LusoBrasileira, a análise pretendida por este ensaio não se imobiliza na estrita objectividade positivista, mas antes articula-se com os contextos concretos e situados do seu objecto de estudo, com o propósito de construir o conhecimento de diferentes racionalidades e mundividências. Porque "o trabalho de tradução é o procedimento que nos resta para dar sentido ao mundo depois de ele ter perdido o sentido e a direcção automáticos que a modernidade ocidental pretendeu conferir-lhe ao planificar a história, a sociedade, a natureza" (SANTOS, 2006: 124).

\section{A CorrespondênCIa Luso-Brasileira: História e Protagonistas}

As 127 cartas que constituem a compilação Correspondência Luso-Brasileira (CARDOSO e PINTO da FRANÇA, 2008) ${ }^{1}$ cobrem um período cronológico situado entre 1807 e 1823 e são da autoria de diversos membros das famílias Pinto da França e Garcez, pertencentes à pequena nobreza rural do Norte de Portugal e, na sua maior parte, há muito emigrados no Brasil ou a este território ligados pela emigração de familiares próximos.

O primeiro volume, intitulado "Das Invasões Francesas à Corte no Rio de Janeiro", contém as 68 cartas trocadas no período de 1807 a 1821, na sua maioria entre Luís Paulino de Oliveira Pinto da França e o sogro e cunhados da família Garcez. Luís Paulino, oficial do exército, nasceu em Cachoeira, perto de Salvador da Baía, no Brasil, a 30 de Junho de 1771, e neste país faleceu a 8 de Janeiro de 1824, no posto de general. Regressado a Portugal ainda com poucos meses, foi criado no Porto, formouse em Direito na Universidade de Coimbra e tomou parte muito activa no movimento patriótico que expulsou os invasores franceses do Porto. Embarcou em 1812 para o

Todas as referências serão provenientes desta edição e as respectivas páginas assinaladas no texto, entre parênteses. ISSN 0034-9631 (Impreso)

Vol. LXXIX, Núms. 244-245, Julio-Diciembre 2013, $817-842$ ISSN 2154-4794 (Electrónico)
Rio de Janeiro, onde assumiu o comando do regimento de cavalaria, como coronel. Elevado a general, a Baía elegeu-o como deputado às Cortes Constituintes de 1821, em Lisboa. Em 1823, foi enviado por D. João VI à Baía para ajustar um armistício com os revolucionários brasileiros. As forças portuguesas tinham porém abandonado já a Baía e, por isso, regressou ao Rio de Janeiro, onde devia juntar-se a outros negociadores. D. Pedro recusou-se a negociar com a comissão portuguesa, que decidiu seguir para Lisboa. Pinto da França ficou retido no Rio de Janeiro, por ter entretanto adoecido, e tentou a viagem em Dezembro de 1823, a bordo do brigue "Glória", mas faleceu tragicamente no mar, antes de chegar a Portugal. Cultivou a poesia, de que se publicaram algumas composições no Jornal de Coimbra, Parnaso Brasileiro e Miscelânea Poética do Rio de Janeiro. Foi fidalgo-cavaleiro da casa real, marechal de campo, cavaleiro das ordens de Cristo, Nossa Senhora da Conceição e Torre e Espada, e condecorado com a medalha de ouro da Guerra Peninsular. A sua biografia repartida entre dois países pode resumirse na frase "Sim, eu tenho duas Pátrias: a Bahia e o Porto. Aquela me viu nascer, esta cuidou dos meus primeiros dias e os encantou com as suas delícias", com que abre uma carta enviada da Baía, em Agosto de 1820 (vol. I, p. 196).

Podemos acompanhar o percurso biográfico e geográfico de Luís Paulino através dos remetentes e destinatários da sua correspondência. Neste primeiro volume, as cartas de 1807 a 1813 são ainda enviadas de Chaves para Bragança e Penafiel, fruto da participação dos membros masculinos de ambas as famílias na luta contra os invasores franceses. A partir de 1813, e até 1819, com o regresso do agora coronel Luís Paulino ao Brasil, as cartas começam a ser endereçadas a partir da corte no Rio de Janeiro, para os sogros e familiares em Penafiel e no Porto, bem como para os cunhados emigrados na Baía. Nos três anos seguintes, trocam-se cartas entre a Baía, para onde Luís Paulino se mudara em 1819, após uma atribulada viagem por mar, e os mesmo destinatários, no Rio de Janeiro, no Porto e na própria Baía.

Os temas recorrentes neste primeiro conjunto de missivas são a resistência às invasões francesas, quando em território português, e, depois da viagem para o Brasil em 1813, a vida na corte do Rio de Janeiro, com suas faustosas festas palacianas, intrigas políticas e jogos de influências, bem como os primeiros sinais de mudança e ventos de independência, com a revolta de Pernambuco, em 1817, em cuja repressão Luís Paulino desempenhou papel de relevo, o que lhe valeu grandes honrarias e promoção na carreira militar. As cartas da Baía, onde Luís Paulino reside aquando da revolução liberal do Porto em 1820, são dominadas pelas transformações políticas em que toda a família, tanto em Portugal como no Brasil, se vê envolvida. No geral, as cartas de Luís Paulino estão juncadas das mais reverenciais alusões ao soberano português e de loquazes testemunhos da sua própria fidelidade enquanto servidor, possíveis estratégias de auto-protecção em caso de um muito provável extravio. Com efeito, toda a correspondência alude à insegurança dos correios, navios e portadores, razão pela qual muitos nomes estão encriptados e

Revista Iberoamericana, Vol. LXXIX, Núms. 244-245, Julio-Diciembre 2013, 817-842 ISSN 0034-9631 (Impreso) ISSN 2154-4794 (Electrónico) 
diversas narrativas surgem truncadas ou plenas de alusões e subentendidos, que apenas um destinatário muito próximo conseguiria descodificar.

O segundo volume, intitulado "Cartas Baianas: O Liberalismo e a Independência do Brasil", congrega as 59 cartas trocadas no período crucial de 1821 a 1823 e são maioritariamente endereçadas a Luís Paulino, agora residente em Lisboa enquanto deputado às primeiras cortes liberais, por sua mulher, Maria Bárbara Garcez Pinto de Madureira, seus filhos e cunhados, que permaneceram no Brasil. Perderam-se contudo todas as cartas enviadas em resposta por Luís Paulino, a partir de Lisboa. Deste modo, as cartas têm como origem geográfica Salvador da Baía e os engenhos de Aramaré e do Caboto, algures entre Santo Amaro e Cachoeira, no Recôncavo Baiano, nas imediações do rio Paraguaçu, e como destino Lisboa. Em 1823, reflectindo o trágico regresso de Luís Paulino ao Brasil e as malogradas negociações junto dos independentistas, trocam-se cartas de teor dramático entre a Baía e o Rio de Janeiro, onde o destinatário adoece e onde embarcará para a derradeira viagem.

Este segundo conjunto de missivas é dominado pela narração dos conflitos que precederam a adesão da Baía à causa da independência, com um profundo conhecimento participante dos eventos históricos em causa, bem como pelas questões inerentes à direcção do engenho de açúcar da família. Consumada a independência do Brasil, emerge nas cartas o dilema familiar da opção entre as duas pátrias: Portugal ou Brasil? A 13 de Abril de 1822, Maria Bárbara escreve de forma bem significativa: "Amo Portugal, gosto do Brasil e desejo o bem" (vol. II, p. 88). E é também neste segundo volume de cartas que ganha protagonismo a figura feminina excepcional de Maria Bárbara Garcez Pinto de Madureira, senhora de engenho e de um peculiar percurso de trânsito e tradução intercultural.

Maria Bárbara Garcez nasceu em Penafíel, em 1779, e casou aos catorze anos com Luís Paulino, amigo e condiscípulo em Coimbra do seu irmão mais velho, José Garcez Dele terá dois filhos (Bento e Luís Paulino Filho) e duas filhas (Sabina e Maria Francisca). Durante as invasões francesas, o marido coloca-a em segurança no Brasil, em Salvador da Baía, sua terra natal. Em 1813, vai juntar-se ao marido no Rio de Janeiro. Ali faz vida de corte até 1819 , altura em que regressa à Baía, de onde nunca mais regressará Portugal, apesar das saudades de que tanto se lamenta nas suas cartas. Viúva em 1824 sobre ela recai há muito a responsabilidade da exploração do engenho de Aramaré, que administrará com grande energia até à data da sua morte, em 1851. O estilo das suas cartas numerosas surpreende pela cultura, lucidez e pela originalidade de expressão, numa mulher nascida na província nortenha na segunda metade do século XVIII, numa família da fidalguia rural, grupo social em que grassava a ignorância, sobretudo entre as mulheres. Mas foi contudo nessa classe, da nobreza das províncias, entre a toga e espada, que se recrutaram os "progressistas", permeados dos ideais pré-revolucionários, que constituíram os contingentes da liderança liberal. Nas suas cartas, Maria Bárbara cita Camões, reproduz máximas latinas e reporta-se constantemente aos novos conceitos

Revista Iberoamericana, Vol. LXXIX, Núms. 244-245, Julio-Diciembre 2013, $817-842$ $\begin{array}{ll}\text { ISSN 0034-9631 (Impreso) } & \text { ISSN 2154-4794 (Electrónico) }\end{array}$ românticos de "pátria”, "nação", “independência”e "poder constitucional”. Não se coíbe de exprimir um intenso afecto pelo marido e os mais violentos sentimentos contra os seus inimigos.

A correspondência de Maria Bárbara permite-nos, acima de tudo, seguir "ao vivo" o percurso de transição intercultural de uma dama provinciana portuguesa que se transforma em senhora de engenho no Recôncavo Baiano, em plena guerra da independência, narrando na primeira pessoa o processo de negociação de uma nova identidade. A origem sócio-cultural de Maria Bárbara situa-se na chamada "nobreza das províncias", um universo vasto, heterogéneo e ainda escassamente documentado. No geral, essa pequena nobreza vivia numa permanente situação económica precária, limitada à preponderância local. Os seus filhos eram invariavelmente encaminhados para o serviço militar, para a magistratura ou para as carreiras eclesiásticas, como forma de manter a casa de família e a miragem de alguma ascensão social. Para as filhas, restava "achar-lhes marido" com posses ("Ao menos, quando tenha dinheiro, tudo está coberto, sendo, como dizem os de cá [Baía], gente branca", carta de 1807, vol. I, p. 50) ou remetê-las, coercivamente e sem qualquer vocação, para um convento, como os "conventos de Vila do Conde e Arouca, que eram bons e custavam pouco" (vol. I, p 50). Com efeito, e citando o prefácio de António d'Oliveira Pinto da França ao primeiro volume, "exaustivamente se optava pelas soluções de recurso à toga, ao Exército e à Igreja, através de sinecuras destinadas a 'arquivar' indiscriminadamente seres humanos que não produziam, viviam do Estado e progressivamente agravavam a ruína nacional. As cartas reflectem bem o fenómeno de dependência dum Estado caduco, um poder e uma elite que viviam promiscuamente, o primeiro a conceder benesses, a segunda a intrigar para as obter" (16)

Para os Garcez e os Pinto da França, cujas casas subsistiam com grandes dificuldades, através do recurso à nomeação de juízes administradores que iam adiando as penhoras, 0 Brasil representara a grande oportunidade de recuperação económica, a que se veio somar a presença de Luís Paulino junto da corte e o acesso privilegiado ao soberano, que lhe permitiu obter sucessivas graças. Daí que, graças ao patrocínio de um tio desembargador, há muito ali fixado, e à influência de Luís Paulino, todos os irmãos Garcez (António, Antão, Feliciano, Manuel e Henrique), à excepção de José, encontravam-se já radicados no Brasil, nos anos que precederam a revolução de 1820. Por estas razões, a progressão nas carreiras e a obtenção de empregos e mercês ocupam uma parte considerável desta correspondência transatlântica, juntamente com os pedidos de toda a espécie que choviam do Porto e de Penafiel, apresentados por parentes, amigos e vizinhos, desejosos de uma palavra junto dos ministros reais, que lhes satisfizesse as pretensões.

Ao contrário dos cunhados residentes no Brasil, e sujeito às suas críticas mais severas, Luís Paulino não se poupa às despesas inerentes a quem pretende "representar" numa corte onde a vida era caríssima e o luxo extraordinário. A exibição pública do status - o "capital simbólico" de Pierre Bourdieu (BOURDIEU, 1997 [1994]) - é feita

Revista Iberoamericana, Vol. LXXIX, Núms. 244-245, Julio-Diciembre 2013, $817-842$ ISSN 0034-9631 (Impreso) $\quad$ ISSN 2154-4794 (Electrónico) 
à custa das maiores despesas, que o regresso à Baía, em 1819, onde Luís Paulino faria a "primeira figura, depois do governador"(vol. I,p. 154), como inspector-geral da cavalaria da província, leva ao auge. Enquanto Luís Paulino narra com orgulho as mercês que a mulher recebe das "Grandes do Reino" por seu intermédio (vol. I, p. 177), os irmãos de Maria Bárbara olham-no como um megalómano, vaidoso e dissipador, prestes a arruinar-se e arrastando consigo a família, como parece comprovar o naufrágio sofrido pelo casal e duas filhas na viagem entre o Rio de Janeiro e a Baía, tal era a pressa de tomar posse do cargo outorgado por D. João VI ou, no dizer de Antão Garcez, “correndo em busca de honra e dinheiro" (vol. I, p. 172 ):

E veja bem a bela notícia que também neste mês recebi! Saiu [Luís Paulino] daqui a 19 de Agosto, para a Bahia, com toda a família, em ocasião de boa monção, em que se pode chegar com 5 ou 6 dias de viagem. Porém, não o quis assim a sorte. Meteu-se num brigue inglês, a fim de evitar algum insulto dos corsários. Fretou-o por sua conta e, à moda do seu génio, saiu com a Mana bem doente. Foi tal a infelicidade que, ao fim de 17 dias, na barra falsa da Bahia, deu à costa às 5 da manhã, ainda com pouca luz. Não posso contar-lhe o que me diz a nossa Irmã, pois não me atrevo. Porém, form ideia de duas pobres Senhoras, com a morte à vista, no estado que estariam, até mesmo quando foram postas no meio da areia, ao pé duma ilha quase de gente como, ou pior, que corsários. Enfim, não se pode imaginar tal aflição até ao momento em que lhes acudiram. A sua carta consterna. A sua sede foi grande, o que puderam salvar estav destruído, quase tudo. Veja, a nossa pobre Irmã e Família o que sofreram e para quê, meu irmão? Isto só à vista. Todos os dias lhe vejo menos arranjo ao nosso Cunhado. Tudo é fartura, tudo são honras e, enfim, nada me importaria, mas é casado com uma Irmã a quem amo. Ele está cada vez mais insuportável. Deus lhe dê um momento em que pense que pode acabar e deixar uma Mulher e filhos do seu próprio génio. [...] Conheço-o e conheço-me. Agora é feito outro e sei que é filho da Bahia... (vol. I, pp. 172-3)

Aos olhos do senso-comum expresso pelo cunhado, Luís Paulino é, cultural e individualmente, "filho da Baía", apesar de na vida pública ser um feroz defensor da união e agente da corôa portuguesa. Essa filiação cultural, essa miscigenação intercultural, justificaria o seu génio ambicioso e impetuoso, bem como a atracção temerária pelas infindáveis riquezas e oportunidades do Brasil. Por sua vez, Luís Paulino mostra-se ciente do perigo a que expusera a família, mas prefere relevar o seu próprio heró́smo e capacidade de liderança na narração que faz do naufrágio, apresentando-o como mais um dos muitos reveses da fortuna que conseguiu vencer com sucesso. ${ }^{2} \mathrm{Na}$ sua demanda

\footnotetext{
"Tua Irmã e Sabina, que saltaram da cama em camisa, corriam como doidas e quase sem sentidos, de uma parte para a outra. Maria Francisca, nua, e que elas trouxeram a rasto, dava gritos e parecia entender o perigo. Considera como eu estaria. Eram 4 para as 5 horas da madrugada. Já corria a animá-las e a dizer-lhes que sossegassem, já corria a um lado e ao outro, gritando à gente que não perdesse o acordo

Revista Iberoamericana, Vol. LXXIX, Núms. 244-245, Julio-Diciembre 2013, $817-842$ ISSN 0034-9631 (Impreso)
}

de riqueza, são inúmeras as vezes em que Luís Paulino exprime o seu profundo fascínio pelos faustos do Brasil. Em 1814, pouco depois da chegada ao Rio de Janeiro, escreve ao sogro: "Este País é belo, grande e rico, mas por isso mesmo quem aqui tem $200 \mathrm{mil}$ cruzados não tem para fazer figura nenhuma e se pode dizer mesmo que é pobre, para viver entre gente" (vol. I, p. 92). E também:

É uma terra caríssima e de um luxo extraordinário pela sua natural grandeza e riqueza. Eu já lhe tenho dito coisa alguma a respeito dos gastos e luxo deste País, que lhe parecerá extraordinário, mas persuada-se que lhe não tenho figurado nem uma ligeira sombra do que isto é. Hoje, não há no mundo uma Corte de mais carestia que esta Parece que não se faz caso de dinheiro. Não aparece traste rico que se não venda logo as coisas de gosto mais esquisito aqui vêm, porque, em outra parte, ninguém as pagaria. Há poucos dias chegaram aqui louças e porcelanas da maior raridade. Venderam-se xícaras e pires por 30 mil réis cada uma. Já é coisa grande. Pois saiba, ainda houve Senhoras que desdenharam e que disseram que xícaras de 30 mil réis não podiam se boas para um chá de aparato. Maria Bárbara tem testemunhado isto com admiração e zanga dum tal luxo. [...] esta terra é boa. Porém, é para quem tem emprego lucrativo, porque os que vivem dos seus bens têm grandes gastos e o que vale é serem também grandes os rendimentos dos proprietários [...] aquilo [o engenho de Aramaré] não tem dado açúcar, tem dado e vai dando muito ouro. São estas as melhores propriedades do mundo e as dessa terra, na verdade, só dão dinheiro de sardinhas. (vol. I, pp. 92-3)

No decorrer do século XIX brasileiro, o sentido da riqueza ostentatória reforça-se, passando a significar cada vez mais a qualidade visível dessa riqueza e a sua utilização na convivência social. Em 1819, Luís Paulino escreve ao cunhado José, o único que se quedara em Portugal, "Não duvides de ver-me caminhar a grandes empregos, mesmo de alcançar um título" (vol. I, p. 155) e, no ano seguinte, "A roda dos meus parentes aqui é da mais pura e melhor nobreza, vive toda em abundância e esplendor e, portanto, não

Uns lá me entendiam, outros não me entendiam (porque o navio era inglês e inglesa toda a sua tripulação) e outros não me obedeciam e cada um tratava de si. Enfim, no meio daqueles horores, já à força de promessas, já de ameaças, tratei de aproveitar o bote para salvar as Senhoras e, lançado este ao mar ancei-as a ele. Levando eu debaixo dum braço a Maria Francisca e, debaixo do outro os papéis e ofício ma costa que desconteciam, un rochedos ou virado pelas vagas. Deixo, enfim, miudezas da narração e concluo que, salvas assim, era uma cena tocante ver as Senhoras nuas e soltos os cabelos, beijando a areia e levantando as mãos e olhos para agradecer aos Céus! Os trabalhos que passei para salvar o resto fariam uma larga história. [...] Porém, a minha perda foi muito grande, pois eu tinha fretado o dito navio todo por minha conta e trazia nele, como se costuma dizer, a minha casa em prazo. Para salvar alguma coisa estive dois dias e duas noites na praia, prometendo e gastando um dinheirão e metendo-me continuamente ao mar, rodeado de bandos e bando de bárbaros ladrões, de forma que o que escapou às ondas dificilmente escapava a estes" (vol. I, pp. 179$80)$

27ista Iberoamericana, Vol. LXXIX, Núms. 244-245, Julio-Diciembre 2013, 817-842 ISSN 0034-9631 (Impreso) $\quad$ ISSN 2154-4794 (Electrónico) 
tendo de que envergonhar-me nem afligir-me, não posso estar melhor. Tenho andado agora sobre uma grande barca de vapor, atravessando esta espaçosa Bahia com uma velocidade suma, para assistir a várias funçanatas e convites destes grandes proprietários do Recôncavo" (vol. I, p. 185), e também "Enfim, quem se não trata e não despende não mantém a dignidade da sua representação, nem conserva as suas amizades e eu tenho muitas e boas na Corte" (vol. I, p. 179). Contudo, através da leitura da correspondência trocada pelo casal entre 1821 e 1823, apercebemo-nos de que toda esta ostentação se baseava no endividamento constante, e que a obtenção de letras de crédito e de favores de agiotas sustentava a representação social da família.

Para os personagens desta correspondência, o Brasil é muito mais (ou muito menos...) do que um "novo mundo". O Brasil é um meio que se pretende rápido e fácil de construir fortunas, ou de recuperar aquelas que séculos de indigência e má gestão delapidaram. Fortunas já reais ou ainda utópicas, adquiridas através do comércio, do tráfico, das mercês, do jogo político, da produção de açúcar ou das estratégias matrimoniais: todas estas possibilidades são referidas e ponderadas, em cartas do mais declarado e cruel pragmatismo.

\section{Falam os Homens: (Breves) Palavras sobre as Mulheres}

O primeiro volume da Correspondência Luso-Brasileira é inegavelmente dominado pelas personagens masculinas. Das 68 cartas compiladas, sessenta são escritas pelo punho de homens e centradas em assuntos de política, dinheiro e jogos de interesse. É sintomática uma missiva trocada entre dois dos irmãos Garcez, entre o Rio de Janeiro e Penafiel, em 1818: após longas páginas dedicadas a pedidos, favores, intrigas familiares, alianças estratégicas, questões de dinheiro e heranças - temas que parecem dominar toda a vida, quer em Portugal quer no Brasil - a carta remata com a singela e redutora frase: "Enquanto a mulheres, meu caro, tudo é a mesma coisa" (vol. I, p. 109).

Em todas as cartas, o imperativo cortês de escrever às mulheres, sejam elas esposas, mães ou irmãs, não é esquecido, mas nunca passa de uma intenção sempre adiada, declaradamente negligenciada por falta de tempo (e de valor, presume-se), restrita a meras nota de cortesia no final do texto. No discurso dos sujeitos de toda a acção de toda a escrita - que os homens parecem ser - que representação merecem então as mulheres, meros objectos das suas decisões e parcas atenções? Com efeito, as mulheres são representadas como objectos que urge colocar passivamente nos poucos espaços aceitáveis que a sociedade lhes reserva, nunca esquecendo cautelosamente que "filhas no Brasil aos 12 anos são mulheres feitas" (vol. I, p. 46). Às sobrinhas solteiras, há que providenciar o sustento através das "tornas" do engenho que escaparam ao morgadio. As sobrinhas casadas que contestam em vão a discriminação na herança resultante do morgadio são apelidadas de "tormento" (vol. I, p. 51). Se, apesar de todos os esforços, as negociações para um proveitoso matrimónio falharem, há que remeter a mulher solteira

Revista Iberoamericana, Vol. LXXIX, Núms. 244-245, Julio-Diciembre 2013, 817-842 ISSN 0034-9631 (Impreso) ISSN 2154-4794 (Electrónico) para um convento acessível. Em geral, nas mulheres louva-se a moderação decorrente da educação portuguesa, por oposição ao gosto pelo luxo e a indolência, que serão já características da aculturação brasileira.

$\mathrm{Na}$ pacatez da província portuguesa, era com grande agrado que se recebiam as novidades do distante Brasil, cujo luxo e exotismo seria difícil de compreender, por falta de referentes comuns na sua descrição. Recorde-se: "Eu já lhe tenho dito coisa alguma a respeito dos gastos e luxo deste País, que lhe parecerá extraordinário, mas persuada-se que lhe não tenho figurado nem uma ligeira sombra do que isto é” (vol. I, p. 93). Por isso, muitas cartas contêm detalhadas listagens dos presentes que as acompanham na viagem do Brasil para Portugal, com rigorosas instruções quanto aos seus destinatários e qual a hierarquia a seguir no momento da escolha. Para as mulheres da família, enviavam-se leques, brincos, colares, lenços, esteiras, feixes de açúcar, madeiras, doce de maracujá, café, "chapéus da Costa da Mina feitos pelos negros", flores, pérolas, entre muitos outros objectos "exóticos".

As narrativas transatlânticas escritas por mulheres que subsistem no primeiro volume desta colectânea são as oito breves notas que Maria Bárbara dirige aos pais e aos irmãos em Portugal. Na curta missiva escrita na Baía, em 1812, e endereçada ao pai, em Penafiel, Maria Bárbara, então já com 33 anos, reitera as saudades e a lembrança constantes da família; exprime profunda alegria por em breve ir receber o marido que regressa ao Brasil; refere com orgulho os feitos militares do filho mais velho, Bento, na resistência às invasões napoleónicas; lamenta-se sobre as indefinidas doenças e melancolia de que sofre e termina com algumas notas sobre os dois filhos mais novos, Luís Paulino Filho e Sabina. Juntamente segue uma brevíssima "carta anexa para a mãe", com curtas linhas de "saudade". Dois anos mais tarde, localiza-se nova carta, da Baía para Penafiel, em que Maria Bárbara narra aos pais o aborto que acabara de sofrer, bem como as suas eternas doenças e saudades; alude à queda de Napoleão e à vida da família real no Brasil; refere algumas festas religiosas e palacianas; dedica longas linhas à descrição de intrigas familiares e de jogos de influência na corte; e lamenta-se sobre a "pobreza" em que vive e as desventuras que sofre, devido à pouca ambição e excessiva probidade do marido (vol. I, p. 86). Curiosamente, estas observações são em tudo o oposto daquilo que Luís Paulino escreve ao sogro, apenas uma semana mais tarde: "Sim, sou vítima de altos desejos e empresas e não deixo de ter jeito para aquilo a que me proponho" (vol. I, p. 91).

$\mathrm{Na}$ Correspondência Luso-Brasileira surgem, se bem que de forma breve e quase sempre indirecta, outras personagens femininas, como por exemplo, Maria Libória Máxima Guilhermina, mãe de Maria Bárbara, de que se reproduzem duas cartas, na verdade pequenos exercícios de escrita em estilo barroco, próprios de uma dama nascida de família humilde, que fizera fortuna recente no Brasil. Os textos não mais contêm do que fórmulas de amabilidade, recomendações familiares, lamentos sobre a saúde e os inevitáveis pedidos de favores para o portador. Sobre as duas filhas de Maria Bárbara

Revista Iberoamericana, Vol. LXXIX, Núms. 244-245, Julio-Diciembre 2013, 817-842 ISSN 0034-9631 (Impreso) ISSN 2154-4794 (Electrónico) 
e Luís Paulino - Sabina e Francisca - as cartas complementam aquilo que a biografia comprova. Maria Sabina, dócil e vulnerável, vive sujeita à devoção por um marido brutal e verá morrer cedo a única filha, logo substituída por bastardos mestiços que dissiparão a herança. Na única e breve carta que subsiste de Sabina para o pai, sobre uma recente doença da mãe, a jovem inclui notas extemporâneas sobre a felicidade conjugal em que viveria, com um marido que "parece que todos os dias me ama mais" (vol. II, p 67). Mentira ou ilusão, a verdade é que numa carta quase simultânea Maria Bárbara reitera que Sabina é infeliz, doente, virtuosa e vive isolada no engenho do marido, essa "víbora" que ela ama cegamente. Por seu lado, Maria Francisca é a filha tardia, nascida já no Brasil, que morrerá solteira aos 48 anos, treze anos depois da mãe. Deixará em testamento ao seu sobrinho Salvador, português distante, o sobrado na cidade da Baía prontamente vendido. Devido à sua idade, as cartas contêm apenas os comentários que os pais sobre ela tecem, sempre elogiosos e cientes de que ela é já filha do Brasil: "tem unidas a uma gentil beleza europeia toda a viveza e graça brasileiras" (vol. I, p. 185).

Da leitura das cartas coligidas no primeiro volume, depreende-se que as actividades de mulheres como Maria Bárbara e outras damas das suas relações restringem-se ao mais puro ócio, entrecortado de idas a banhos de mar na Praia do Botafogo, visitas com leitura e comentário de cartas e grande sátira aos hábitos do Portugal rural e provinciano. Em 1814, o recém-chegado Luís Paulino escrevia já: “A pintura da feira, dos socos e capotes, e da rústica fidalguia, por força move o riso, até a qualquer escravo mulato desta terra que é mais polido e açucarado e mais retórico do que era o sábio Frei Bártolo nos seus sermões" (vol. I, p. 99). Será decerto humilhante para o autor da carta, o cunhado José Garcez, em Penafiel, saber que a sua descrição dos hábitos portugueses fora alvo de escárnio público por parte da "Viscondessa de Vila Nova e outras Senhoras de amizade, que estavam com ela [Maria Bárbara] quando chegou a carta" (vol. I, p. 99). Num só parágrafo, Luís Paulino declara o seu afastamento da cultura provinciana portuguesa e exalta o círculo social que abrilhantava o quotidiano da sua família, ciente de que a comunidade de origem de tal tomaria imediato conhecimento.

A ociosidade de Maria Bárbara revela-se nos variados argumentos que evoca para não escrever mais amiúde à família em Portugal, por contraste com o extraordinário volume de correspondência que endereçará ao marido, depois da sua partida para Lisboa. Desde a filha que lhe "tem dado que fazer com os pasmos que lhe sobrevieram na subida dos queixais" (vol. I, p. 143), até à areia que o vento arrasta sobre o papel de carta, passando pelos longos meses a "banhos e ares" em São Cristovão (vol. I, p 113), tudo são pretextos para atrasar a escrita. Numa breve carta de 1818 ao irmão, no Porto, Maria Bárbara, então no Rio de Janeiro, desculpa-se por não lhe escrever com frequência e mantém as mesmas temáticas de há seis anos atrás: o permanente lamento sobre "lágrimas", "rugas" e "tristeza", saudades, a família, o tempo que passa, as doença indefinidas (vol. I, pp. 120-1) ISSN 0034-9631 (Impreso)

Vol. LXXIX, Núms. 244-245, Julio-Diciembre 2013, 817-842 ISSN 2154-4794 (Electrónico)
Para além do evidente quotidiano ocioso, inferem-se daqui as características naturais de uma identidade individual, bem como as dinâmicas próprias de um círculo familiar tão alargado quanto disperso geograficamente. Contudo, muita da apatia e infelicidade expressas nas cartas de Maria Bárbara irá também de encontro às convenções sociais, às expectativas do senso-comum actuante junto dos destinatários. Isto é, Maria Bárbara escreve aquilo que se espera de alguém com o seu papel social de esposa casta, modesta e devota e de filha obediente, apenas afastada dos seus pelos deveres conjugais. $\mathrm{Na}$ realidade, cedo se compreende, pela leitura das (poucas) cartas de Maria Bárbara e pelas (poucas) referências que merece de seu marido e irmãos, que ela toma parte muito activa nas intrigas e conflitos familiares, não se coibindo de assumir partidos e forjar alianças. E é o próprio Luís Paulino quem fornece uma primeira pista sobre a "senhora de engenho" que irá dominar toda esta correspondência a partir de 1821 quando, retido na corte, escreve que não tem tempo para a administração do engenho, tarefa que delega na mulher... ou que ela tomou já para si, muito antes ainda de enviuvar (vol. I, p. 140).

Na correspondência masculina, a mulher apenas assume protagonismo no contexto das alianças matrimoniais, em que o casamento é exclusivamente conotado com obtenção de propriedade e/ou ascensão social. Aqui, as mulheres são simples objectos transaccionados enecessariamente lucrativos para as famílias envolvidas, numa realidade sintetizável na frase com que Luís Paulino alude à intenção de um cunhado em contrair matrimónio: "Ele tem tido constantemente vontade de casar-se, bem entendido, para armar dinheiro" (vol. I, p. 93). Com efeito, o percurso matrimonial dos irmãos Henrique Garcez (homem de corte, brigadeiro do exército brasileiro e comendador da Ordem de Cristo) e António Garcez (desembargador na Baía e no Rio de Janeiro), os mais presentes nesta correspondência, é por demais ilustrativo. Henrique Garcez casa ("toma estado") com uma viúva rica, "feia e velha" e já com muitos filhos, de quem não terá geração: "Henrique pode [...] morrendo a Senhora que não é menina, levar para o Reino $100 \mathrm{mil}$ cruzados [...] Seguraram-me que o rapaz 'chupita' alguns mil cruzados. Deus o ajude!' (vol. I, pp. 93, 97-8). A primeira pretendida de António Garcez casara com outro, pois "venceu o coração e não a lei, porque o modernismo a tudo chega" (vol. I, p. 83). Aos quarenta anos, contudo, casa com uma menina de dezasseis anos, "de boa família, não fidalga", "sem beleza, mas galante" que "me ajudará na velhice" (vol. I, pp. 101 e 163) Em carta ao irmão José, em Portugal, António Garcez descreve com o maior calculismo e frieza as circunstâncias que presidem ao enlace, bem como as relações que de outra forma manteria com o sexo oposto:

Virei a possuir o melhor de 60.000 cruzados por morte do Pai, que é velho, e a Mãe logo que ele falte, se entrega à minha discrição, e já desta quantia receberei em ben vinte. Enfim, não é grande porção, porém não há outras, e se há são meninas daquela idade que querem meninos o que já não sou. Daqui em diante devia acabar namoro, mesmo porque só poderei dar uma fodinha a peso de dinheiro ou furto, mas pelo furto

Revista Iberoamericana, Vol. LXXIX, Núms. 244-245, Julio-Diciembre 2013, 817-842 ISSN 0034-9631 (Impreso) ISSN 2154-4794 (Electrónico) 
lá vem um galiquito que faz acabar mais breve os dias da vida [...] Seguro-lhe que não estou apaixonado rigorosamente, estimo a pequena e as paixões duraram até aos 30 . [...] Já disse que a minha Teresinha traz, em propriedades, valor de 50 mil cruzados e se me promete para a casa logo que nos recebamos, que foram 22. A isso se obrigam. No mesmo dia, antes do laço, se satisfaz a este ajuste. Vem a ser 70 e tantos e, por morte dos velhos, anda de 30 a 40 (vol. I, pp. 144 e 163)

Afirma ainda que vem tratando deste "negócio" há dois anos, com "experiência e segurança", muito satisfeito com a perspectiva de a noiva não demandar luxos pois "tem sido tratada com o sistema da Europa, porque a Mãe é de Lisboa. O Pai, filho das Ilhas. Já isto é um dote no Brasil onde rara é a família que não tenha "cabritos"” (vol. I, p. 163). Depreende-se que o valor da noiva aumentará em proporção inversa à aculturação e miscigenação da famíia. Concretizada a aliança, é ainda com crueza que, no mesmo parágrafo, tanto descreve os mais ínfimos itens do enxoval como resume a consumação do casamento com "pela uma hora principiaram as lágrimas, para se seguirem os gostos" (vol. I, p. 166).

No entanto, Luís Paulino e Maria Bárbara rejeitam com veemência esta aliança, que adjectivam de "vergonha" (vol. I, p. 186), pois o valor pecuniário da noiva não vem acompanhado de título aristocrático, condição ao que parece sine-qua-non para as aspirações do casal, que o noivo injuriado qualifica de "etiquetas ridículas" (vol. I p. 193). Esta suposição comprova-se aquando dos casamentos do filho e da filha mais velhos, Bento e Sabina. Para o primogénito, Luís Paulino traçara objectivos matrimoniais ambiciosos: escolhera-lhe para noiva a filha do barão de Santo Amaro, um casamento que projectaria a família para os píncaros da nobreza local, com "interesse de fazenda a maior esplendor da nobreza [...] cujo dote, fora o que depois havia de vir por herança passava muito de meio milhão" (vol. I, p. 197). Porém, Bento optou por casar com a filha de um coronel, de estatuto social idêntico ao da sua família, o que desencadeou a ira incontida do pai, que rompe com ele, apodando-o nas suas cartas, entre muitas outras expressões disfóricas, de "homem que foi meu filho", "monstro de ingratidão", "monstro e indigno [...] falho de brios e sentimentos", "alma destituída do amor da glória e da boa representação", "quem não tem altos sentimentos não é meu filho", "vil escória da minha geração", que casou "como um negro, às escondidas" (vol. I, p. 197-8). Este caso ilustra contudo a afirmação crescente do individualismo afectivo, que por vezes leva a que prevalecessem os destinos pessoais em relação aos interesses da casa familiar.

Para compensar este contratempo na sua estratégia de promoção social, Luís Paulino conferiu expressamente ainda maior brilho ao casamento da filha Sabina com Rodrigo António Brandão Pereira Falcão, futuro barão de Belém, homem abastado que, com os bens que receberia em herança, poderia vir a ser um dos vassalos mais ricos de todo o reino: "O meu pesar, longe de me fazer esmorecer a respeito da magnificência e dignidade, me estimulará para os testemunhar mais nesta aliança tanto do meu gosto" (vol. I, p.

Revista Iberoamericana, Vol. LXXIX, Núms. 244-245, Julio-Diciembre 2013, 817-84 ISSN 0034-9631 (Impreso) ISSN 2154-4794 (Electrónico)
192). Os qualificativos deste enlace, descrito como o verdadeiro contrato comercial que era, são bem eloquentes: "ilustríssima distinção", "gastador e valentão", "nascido com 300 escravos para o servir", "melhor do que ele, em qualidade de nascimento, ninguém", "contrato em vantagem", "dignidade", "minha escolha e contento", "glória e decência", "aparato", "magnífico", "estadão", "pompa", "brilhantismo", "criados fardados de novo e ricamente", "magnificência e delicadeza do jantar", "baile de aparato brilhantíssimo", "segundo todas as formalidades dos casamentos dos fidalgos e pessoas de qualidade" (vol. I, pp. 197-201). A ostentação do luxo - característica da vida no Brasil que Luís Paulino reconhecia fascinado desde as suas primeiras cartas - eclode na detalhada descrição das formalidades e pompa do casamento de Sabina, em carta ao cunhado José Garcez, com instruções para que esta fosse lida à família da mulher, em Penafiel. Luís Paulino comprova e divulga assim o seu sucesso na demanda comum a todos os trânsitos interculturais Portugal-Brasil: a obtenção de fortuna e a ascensão social ${ }^{3}$.

Quase em simultâneo, Maria Bárbara escreve sobre o mesmo assunto ao irmão, muito mais lacónica e referindo apenas a "regra e aparato" do casamento da filha (vol. I, p. 202-3). Exprime contudo alguma preocupação pelo futuro de Sabina (que os seus irmãos no Brasil partilham entre si sem rodeios, pois era já do conhecimento público que o noivo tinha vários filhos ilegítimos mestiços) e pela raiva do marido em relação ao filho Bento. Contudo, é inexorável ao secundar o marido no desprezo pelas mulheres "inferiores em nobreza e idade" que os "homens da família" (Bento e o seu irmão António) desposam. Maria Bárbara comunga, sem qualquer dúvida, das ambições e preconceitos actuantes no senso-comum desta pequena nobreza sem título, transferida pelas circunstâncias para um "novo mundo" em que, na verdade, pouco ou nada mudara

Como causa e consequência da ambição sócio-material dominante, a sociedade baiana oitocentista apresentava-se fortemente hierarquizada. No topo da sociedade do Recôncavo, encontrava-se uma aristocracia rural que aspirava a condições de nobreza nos moldes que se verificavam em Portugal. Kátia Mattoso reitera que, no Brasil, uma pessoa nobre poderia ser reconhecida pela sua linhagem ou pela colocação dos seus bens e educação ao serviço da pátria. Mesmo que um indivíduo não fosse fidalgo de

Ironicamente, o casamento de Bento será feliz e com geração. Bento virá a ser nobilitado $\left(1^{\circ}\right.$ conde da Fonte Nova, par do reino, general, cavaleiro de Torre e Espada) e, tanto ele como a sua mulher e filhos - já "perdoados", mas sempre com grande resistência por parte de Luís Paulino e Maria Bárbara - constituirão o grande esteio familiar desta última durante a guerra da independência. Por seu lado, como foi já apontado, Sabina morrerá negligenciada aos 56 anos, dois anos depois da mãe e um ano antes do marido, sem filhos sobreviventes, e toda a fortuna sera delapidada pelos descendentes ilegítimos de Rodrigo Falcão, falecido em 1855, durante uma epidemia de cólera. Falcão revelar-se-á fervoroso independentista e abandonará prontamente todo e qualquer contacto com os sogros, evidenciando ainda em vida de Luís Paulino grande animosidade para com este, baiano de nascimento mas representante de D. João VI no armistício com os revolucionários.

Revista Iberoamericana, Vol. LXXIX, Núms. 244-245, Julio-Diciembre 2013, 817-84 ISSN 0034-9631 (Impreso) ISSN 2154-4794 (Electrónico) 
linhagem, poderia ser agraciado pelo imperador de acordo com a sua disposição em servir o império (MATTOSO, 1997: 154). Anna Ribeiro de Araújo de Goés, senhora de engenho da segunda metade do século XIX, deixou uma elucidativa referência a esse respeito:

Os Araújo Góes, do Catu, que ali ocupavam vasta área de território, gozaram sempre da reputação de homens probos, cumpridores de seus contratos, nunca desmentindo d espécie de aristocracia formada pela classe muito considerada dos senhores de engenho, que era a segunda nobreza do país, como era na França a magistratura. Tendo gozado de grandes privilégios nos tempos coloniais, conservavam ainda bastantes garantias no Império, como ainda vi na minha mocidade. (BITTENCOURT, 1992: 1)

Kátia Mattoso ressalva que, apesar da aspiração ao status de nobreza, os senhores de engenho do Recôncavo constituiam-se essencialmente numa aristocracia de riqueza e poder, que desempenhou e assumiu muitos dos papéis da nobreza portuguesa. É essa aristocracia que dá à Baía certas tonalidades da sua opulência. Mattoso defende ainda que o casamento endogâmico seria uma das principais tácticas utilizadas por esses clãs para expandirem as suas possessões e reforçarem laços sociais e políticos entre aristocracia local (MATTOSO, 1997: 154 e segs.; MATTOSO, 1988: 136-59).

Porém, todas estas preocupações dos Pinto da França e dos Garcez cedo ficariam para trás, com a eclosão no Porto do pronunciamento liberal de 1820, que conduziu à reunião das cortes e ao regresso do rei a Portugal, com as consequentes movimentações que levarão à independência do Brasil, sob a égide de D. Pedro. Neste conturbado momento da história vai emergir também, no microcosmos da Correspondência LusoBrasileira, uma renovada personagem feminina, tão independente quanto a nova nação.

Escreve a Mulher: Maria Bárbara, Senhora e de Engenho

O segundo volume da Correspondência Luso-Brasileira (1821-1823) é dominado pela assunção de Maria Bárbara Garcez Pinto de Madureira, agora com 43 anos e administradora plenipotenciária do engenho de açúcar de Aramaré, adquirido pelo sogro em meados do século anterior. Pela forte ligação que havia criado com o Brasil e sentindo-se indispensável à gestão do engenho, não acompanha o marido a Portugal, quando este é eleito deputado às cortes constituintes de 1821. Tais circunstâncias estão na origem das 25 cartas de Maria Bárbara aqui compiladas, parte do vasto volume de correspondência trocada entre o casal, antes da morte de Luís Paulino, em Janeiro de 1824 As cartas de Maria Bárbara distinguem-se agora pela sua vivacidade e rigor descritivo, bem distantes das ociosas notas de cortesia e lamento, até então endereçadas aos irmãos e à família em Portugal. Funcionam também como uma chave para a compreensão de muitos dos subentendidos que juncam a correspondência de autoria masculina, ao desvendarem tanto o verdadeiro referente de muitas das suas alusões veladas, como o verdadeiro estado das finanças familiares, por oposição às descrições de pompa abundância que Luís Paulino reiteradamente endereçava aos cunhados.

Nos seus textos, Maria Bárbara ataca e acusa com singular fervor os inimigos políticos do marido ausente e afirma quase ter tomado a iniciativa de mandar publicar documentos comprometedores contra os conspiradores. Afirma-se capaz de matar incitando Luís Paulino à vingança e à acção, queixando-se da brandura geral dos costumes e da justiça: "Eu quero ver punidos os infames", "Se pudesse queria arrancar-lhes as línguas $[. .$.$] beber-lhes o sangue", "Eu, eu tenho ânimo de tirar-lhe aquele coração",$ "Desafronta-te ou, aliás, eu tiro-lhe a vida. Sou capaz, não duvides" (vol. II, pp. 57-

61). Enquanto senhora de engenho, Maria Bárbara vive em constante trânsito entre a Baía e Aramaré, onde permanece sozinha por largas temporadas, contra a vontade de filhos e parentes, pois o interior e o recôncavo baianos estavam já em poder das forças independentistas. A viagem entre a cidade de Salvador e o engenho de Aramaré, no extremo interior do Recôncavo, não estava isenta de dificuldades e era feita por barco até Santo Amaro e depois a cavalo ou de carro puxado a bois ou a cavalos, durante cerca de vinte quilómetros. Um dos riscos do isolamento revela-se quando Maria Bárbara cai doente de "febre" e nenhum médico de Salvador aceita fazer a viagem para a tratar, sob o "dilúvio" que cai incessantemente. Com grande dificuldade e despesa, um médico militar e a filha Sabina acabam por velá-la durante semanas (vol. II, p. 65). Incidentes como este e o passado episódio do naufrágio recordam que o Brasil ainda era em muito um território hostil e de difícil domesticação para a elite colonial branca.

As cartas trocadas tanto com o marido como com os filhos, Bento e Luís Paulino Filho, constituem uma verdadeira "correspondência comercial”, em que Maria Bárbara menciona quantias e valores precisos sobre as safras, anuncia a aquisição de gado, decide as rendas a retirar ou não da parte dos filhos e narra a severidade com que gere e disciplina os serventes:

Dar-me-ei por feliz se fechar no Natal com mil e duzentos pães. Vim achar a boiada magríssima e tudo por fazer. Já se enxugou um tabuleiro vizinho ao nosso e vou cuidar doutro para o Bento, mas a este não tiro renda nem meação; ao que dou ao Luís só perdoarei a renda. Se eu para aqui não venho, não teríamos em breve que moer, nem os nossos lavradores de Xangô [os filhos], como tu lhes chamas. Já comprei 34 bois. Agora estou à espera de potros, para comprar ao menos 36; mas os gastos são horrorosos, a família dobrou-se-me, e de que modo! Deus se lembre de mim. [...] o alambique vai indo mal, pois Peregrino, Mocinho e Onofre, ladrãosíssimo. [...] Enfim, a falta de assistência agora ao Engenho não me faz mal, pois eu sei regular-me. Ah, pobre, pobre Aramaré, tens sido vítima grande grande do ladrão Coelho. Tenho achado coisas! Se partíssemos juntos, asseguro-te que Aramaré se acabava de todo. Isto a que estava votado. [...] Sim, meu Luís, estou só, só. Falas-me que se te demorares me mandas

Revista Iberoamericana, Vol. LXXIX, Núms. 244-245, Julio-Diciembre 2013, 817-84 ISSN 0034-9631 (Impreso) ISSN 2154-4794 (Electrónico)
Revista Iberoamericana, Vol. LXXIX, Núms. 244-245, Julio-Diciembre 2013, 817-842 ISSN 0034-9631 (Impreso)

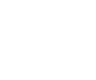


buscar. Eu bem gosto teria de abraçar-te, mas crê que, se não tinha ficado, o Engenho de Aramaré, dentro em pouco, era campo onde foi Tróia! (vol. II, pp. 63, 89 e 105).

Através da representação que Maria Bárbara faz de si própria nas cartas, concluise que os filhos prestam-lhe contas rigorosas e que a incompetência daqueles a tornou indispensável à sobrevivência do engenho. Justificará assim a sua opção por permanecer no Brasil e deixar partir o marido, exacerbando talvez a sua preocupação com a família crescente, com os escravos a sustentar e com a necessidade de criar poupança e assegurar o futuro: "E acabo por dizer-te que até ao ano de 1824 quererei achar-me em Portugal. Quero acabar os meus dias na minha Pátria, beijar ainda a mão querida duma Mãe abraçar os irmãos que me restam. Mas não quero deixar os meus sem pão e, para segurar isto, é forçoso sacrifícios" (vol. II, p. 132). O "sacrifício" da permanência no Brasi adquire um valor acrescentado nos momentos de desânimo e de perigo, como aqueles que se seguem à partida de Luís Paulino para Portugal (escreve Maria Bárbara: "Infame gente. Eu a detesto. Vou-me, vou-me embora logo que a sorte o permita. Quero deixar um país onde a Ciência e a Virtude são ramos desconhecidos", vol. II, p. 58), ou que advêm do caos criado pela guerra da independência: "Da Mãe nada lhe posso dizer, pois há quatro meses que dela nada sei, porque não há comunicação alguma. [...] Não sou exagerado: o soldo não se paga, aqui tudo está caro, já não comemos senão salgados. [...] todos os portos estão proibidos de mandar para a Cidade qualquer género que seja. [...] eu espero em Deus que a minha Mãe nada lhe há-de acontecer, pois ela é uma Senhora de muito respeito e juízo; portanto hão-de respeitá-la. E mesmo a sua estadia lá fora [no engenho] fará com que não lhe confisquem os bens" (vol. II, pp. 138-9), escreve Bento, em Março de 1823. Neste juízo negativo permanecia já há muito o primogénito, para quem aquele país "não é habitado por gente que conhecesse o grande Mundo e que nele tem vivido. Aqui não se vive, vegeta-se", proposição com que rematava uma carta de 1818, dirigida ao tio em Portugal (vol. I, p. 146). Esta visão pessimista de Bento é em tudo oposta àquela com que o seu pai, em simultâneo, louvava ao mesmo destinatário as opulências do Brasil.

Assumindo o papel de mãe-coragem, líder na ausência do marido, o discurso de Maria Bárbara nunca expõe dúvidas nem solicita autorizações. Ela narra sem vacilar as decisões administrativas tomadas, no contexto de uma evolução/libertação identitária, que as circunstâncias políticas e históricas propiciaram. Porém, e de modo a moderar a sua assertividade, sem raiar a emancipação e permanecendo sempre dentro dos cânones do expectável, Maria Bárbara matiza a sua escrita com lamentos e saudades e afirma-se doente mas trabalhando incessantemente a bem da família e por amor ao marido, agora sem tempo para ir aos "banhos" que lhe fariam recuperar a saúde.

Era relativamente comum que as mulheres dos maiores fazendeiros, quando viúvas, assumissem toda a autoridade e controle dos bens, nos quais se incluíam os escravos. Charles Boxer é categórico ao afirmar que "não pode restar dúvida de que uma viúva

Revista Iberoamericana, Vol. LXXIX, Núms. 244-245, Julio-Diciembre 2013, 817-842 ISSN 0034-9631 (Impreso) ISSN 2154-4794 (Electrónico) rica ou pobre, podia levar uma vida livre, menos presa e recatada do que uma mulher casada e suas filhas" (BOXER, 1977: 75). Na sua História da Vida Rural no Brasil, Mary del Priore e Renato Venâncio informam que, no ano de 1759, havia já seis senhoras de engenho em Santo Amaro, bem como 37 senhores de engenho. No censo de Goiás, em 1818, encontram-se também várias donas de engenho, como Dona Marina Pereira, que tinha a propriedade por compra e onze escravos no trabalho da lavoura (PRIORE e VENÂNCIO, 2006: 29-46 e 101-22). No mundo quotidiano, o elemento feminino era o centro de todas as rotinas familiares e a sua actividade nessa esfera detinha grande significação social, comparada às actividades do trabalho no espaço público reservado aos homens. Era responsabilidade das senhoras da época toda uma série de serviços e trabalhos de casa: lidar com as equipas de cozinheiras, amas de meninos, carregadores, ganhadores, fiadeiras, costureiras, lavadeiras, passadeiras, pintores, pedreiros e barbeiros. A senhora de engenho detinha uma função proeminente na harmonia do quotidiano da família patriarcal (MATTOSO, 1997: 157). A já citada Anna Ribeiro de Araújo de Goés defendia que as mulheres deveriam estar preparadas para tomar o lugar dos homens, se a situação a tal conduzisse, o que fica claro nos enredos dos seus romances e folhetins moralistas. Em Letícia (1908), por exemplo, a protagonista assume o lugar do pai após a sua morte, ordenando os escravos, negociando com os atravessadores e vendendo a produção. Mas Maria Bárbara assume tais funções em vida do marido, quando ainda nem mesmo se previa o trágico desfecho de Luís Paulino, nem o perigo das expropriações na fase da independência. Conta com o seu pleno consentimento e apoio, mesmo tendo dois filhos varões adultos que, contudo, tudo relatam e justificam perante a mãe, sequiosos de aprovação, como se depreende na carta que Luís Paulino Filho lhe dirige, em Fevereiro de 1822: "O Engenho vai na melhor marcha e seja-me lícito dizer que nunca se fez em anos o que eu tenho feito em dias" (vol. II, p. 66). Ironicamente, quase em simultâneo, Maria Bárbara reporta ao marido a incompetência dos filhos enquanto administradores, o que a tornará a ela vital para a sobrevivência dos recursos familiares. Os protagonistas alteram-se conforme o autor da carta, mas é incontestável que, às funções tradicionais da mulher, Maria Bárbara havia já somado com determinação as funções de gestão e decisão no espaço exterior do engenho, território masculino por excelência, o que apenas comprova o carácter de excepção desta personagem e das circunstâncias familiares e históricas que a rodearam.

No geral, os homens e as mulheres que comandavam as plantações de cana eram seguidos por um grupo diversificado de trabalhadores especializados e agregados, que orbitavam nas suas franjas, prestando ao senhor das terras os seus serviços. Eram mestres-de-açúcar, purgadores, caixeiros, calafates, caldeireiros, carpinteiros, pedreiros, barqueiros, entre outros. A eles juntavam-se outros grupos a animar a vida económica e social das áreas litorais. Mercadores, roceiros, artesãos, lavradores de roças de subsistência e de cana e até mesmo desocupados compunham a população que gravitava em torno de pequenos ou grandes proprietários. O número de escravos que esses dois últimos ISSN 0034-9631 (Impreso) ISSN 2154-4794 (Electrónico) 
segmentos possuíam (de um a várias dezenas) permite inferir a enorme diversidade de origens sociais e de situações económicas. A maior parte dos engenhos aninhava-se na mata, o que se explica pela maior fertilidade dos terrenos bem vestidos de capa verde pela abundância de lenha, necessária às fornalhas, alimentadas num labor que, às vezes, durava dia e noite, oito ou nove meses. Junto dos engenhos era comum instalarem-se alambiques, como sucede em Aramaré. Os engenhos não podiam afastar-se muito do litoral, sob pena de, sendo um só o preço dos géneros de exportação, não competirem com os demais fazendeiros, cujo produto não sofria com as despesas de transporte. Por essa razão, a maior parte dos engenhos localizava-se à beira de rios como o Paraguaçu, o Jaguaribe e o Sergipe, na Baía (PRIORE e VENÂNCIO, 2006: 42 e 36-7).

Eram, sem dúvida, imensas as adversidades que qualquer senhor de engenho, independentemente do seu género, enfrentava num Brasil em plena convulsão. Em todas as cartas familiares desta época, são constantes as alusões a dívidas, a pedidos de crédito, à falta de dinheiro e ao pagamentos de favores, com recurso desesperado ao soldo do primogénito, a agiotas e à venda improvisada de caixas de açúcar. Maria Bárbara afirma que, apesar de previdente e parcimoniosa, tinha ainda maior dificuldade em obter crédito após a partida do marido:

Enquanto ao assistenteAlmeida, já te disse que eu, fazendo mesmo os maiores sacrifícios, na vindoura safra nada quero dele, pois desde que daqui saíste eu não lhe sou em nada obrigada. Até ultimamente me abateu a mesada, pois diz não pode e que faz sacrifícios. Eu é que não posso aturá-lo. Ultimamente, precisando da sua firma nas duas letras vencidas, negou-se sem ter nisto o menor desembolso. [...] Que mundo patife! [...] Pago vestuário de negros, mantas noventa, carretos, tudo, tudo, e o alambique não dá para tudo, pois a aguardente está muito barata, bem como o açúcar. Enfim tu sabes se gosto ou não de poupar, pois gosto muito de dar conta de mim. O pior é estarmos sem cavalos e os bois a morrerem muito. Deus me dê paciência. (vol. II, pp. 93-4)

A tudo isto vêm juntar-se as constantes intrigas políticas, rivalidades familiares, inimizades generalizadas, recusas em "firmar letras", violentas intempéries, doenças, morte de animais, num elenco de contratempos sempre rematado com a corajosa previsão de boas safras e fortuna num futuro indefinido, o tal "depois", quando Maria Bárbara puder por fim entregar a gestão do engenho ao filho e partir para junto do marido, o que nunca virá a suceder. Do conjunto de todas as cartas é possível inferir um padrão retórico recorrente no discurso de Maria Bárbara: os longos parágrafos de lamentação pelos mais diversos motivos (saúde, dinheiro, trabalho, clima, família, política, traições, intrigas, idade) terminam invariavelmente numa breve declaração de esperança que, segundo ela, será motivada em exclusivo pelo desejo de corresponder às preocupações e expectativas do marido. ISSN 0034-9631 (Impreso)

Vol. LXXIX, Núms. 244-245, Julio-Diciembre 2013, 817-842 ISSN 2154-4794 (Electrónico)
Plenamente integrada nas estruturas de pensamento vigentes na sociedade brasileira de então, Maria Bárbara é assumidamente uma senhora de engenho esclavagista, essencialista na sua animalização do colectivo "negro", que se escandaliza com a mera hipótese de emancipação ${ }^{4}$. Exprime o receio de que negros e mulatos, libertos ou escravos, se revoltem a coberto do dissídio entre a elite branca, mas compreende que também neste campo ocorrem manipulações políticas e estratégias alarmistas: "Os malditos bodes e negros são os nossos pecados, que, se fossem de cima, infelizes famílias acabariam às mãos deles horrorosamente" (vol. II, p. 74); "Não suceda, como dizem sucede agora em Pernambuco, que os pretos e pardos (corja do diabo) apedrejam e dão cacetada em todo o lojista" (vol. II, p. 90); "Eu não nego que a mulatada seja infame. E, pois são soberbos, mas como temos boas leis, demos-lhes quem os escute e castigue. Já saberás que a crioulada da Cachoeira fez requerimentos para serem livres. Estão tolos, mas a chicote tratam-se. Aviso-te mais que, em nome dos cativos daqui, há aí quem meta às Cortes requisitos" (vol. II, p. 87). Com efeito, o peso numérico dos escravos na Baía e as revoltas recentes ali ocorridas não podiam deixar de assustar os senhores de engenho, receosos de uma rebelião igual à de São Domingos, que conduziria à república negra do Haiti. A ideia de que apenas as tropas europeias podiam conter os escravos, dada a fraqueza das forças locais, era há muito invocada pelos defensores da união e, decerto com a intenção de captar o apoio dos senhores de engenho, várias vozes exageravam o risco, dando como iminente uma formidável rebelião de escravos. Porém, nem todos se deixavam convencer, como se depreende deste passo de Maria Bárbara: "Todos os dias se finge que os negros são temíveis, a fim de as tropas persistirem aqui. Armem os Regimentos da Província e não tenham medo. Eu estou no Brasil há 12 anos e, falando-se tanto dos perigos que podem haver em razão da escravatura na província da Bahia, no decurso deste tempo, que de mortes que tem havido? Nada, nada, só boas leis e doçura. Tudo o mais é peta" (vol. II, p. 118). Não deixa de ser curioso o emprego da palavra "doçura" para designar as leis e os costumes que regiam a escravatura na Baía.

Atenta aos assuntos políticos, sociais, económicos e militares, que agora dominam quase todas as cartas, o quotidiano familiar tornou-se uma nota residual na correspondência de Maria Bárbara, referida apenas quando afectada pelas circunstâncias históricas. Os filhos, o marido, ela própria tornaram-se actores sociais na plena acepção da palavra, vivendo agora o seu quotidiano em pleno palco da história, um quotidiano que se

Em Goiás, no século xIX, há testemunhos de que as mulheres brancas, além de mães, eram donas de terra e cruéis com empregados e escravos. É certo que a história de submissão da mulher está carregada do mito da fragilidade que justificou historicamente a protecção paternalista dos homens sobre as mulheres. No entanto, na história do Brasil e, especificamente na região de Goiás, a violência por parte da mulher brance, dona de engenho, contra as mulheres negras, escravas, data de meados do século dax, sendo suas senhoras (GODINHO, 2006; SILVA, 2003).

Revista Iberoamericana, Vol. LXXIX, Núms. 244-245, Julio-Diciembre 2013, 817-842 ISSN 0034-9631 (Impreso) ISSN 2154-4794 (Electrónico) 
confunde com a construção da própria história. A narrativa epistolar está juncada de quadros violentos, como o da fuga de Maria Bárbara para bordo de um navio holandês, em Abril de 1822, aquando dos sangrentos episódios na Baía, resultantes da oposição à tomada de posse do governador de armas da província. De todos os acontecimentos oferece uma visão participante, comentada, se necessário contra as versões propagada pelas facções em conflito, pois "Eu vi, eu vi numa Gazeta um oficio [...] Eu vi, eu vi, sou verdadeira testemunha" (vol. II, p. 87). Sem advogar a independência, exigindo apenas um tratamento justo e igualitário para o Brasil, Maria Bárbara não se coíbe de admoestar os políticos e criticar os excessos de todos os intervenientes no momento histórico, sem distinção. Na qualidade de espectadora participante e privilegiada, esclarece e exorta com veemência o marido e seus pares nas cortes em Portugal sobre aquilo que crê ser a realidade da situação e as verdadeiras aspirações da Baía, como se pode verificar nestes excertos de Maio, Junho, Julho e Agosto de 1822, vésperas do "Ipiranga":

Tu não podes formar ideia da rivalidade que há entre Europeus e Brasileiros, e os malditos praistas fizeram este mal irreparável. Não se iludam aí: nada fazem com os brasileiros por força. Doçura e mais doçura, igualdade e mais igualdade. (vol. II p. 106)

As contínuas desordens têm posto esta bela Província em puríssima miséria. Pobres habitantes dela, que bem têm sofrido. E ainda se ralha deles e ainda são insultados. Que mais lhe querem? Dar-lhes ferros? É só o que falta. (vol. II, p. 113)

Eu não entendo de política, mas a meu ver, com bem pouca têm andado sobre um objecto tão melindroso como este do Brasil. Os brasilienses estão sentidíssimos ao infinito com algumas das falas que aí se têm feito relativo a este fértil reino. E, na verdade, os Senhores Deputados que as fizeram assentam que o Brasil é algum covi de negros, onde, perdoa-me, muito se enganarão, mas o pior é que nós pagamos cá o que lá se faz. (vol. II, p. 125)

Eu não posso por mais tempo calar-me. Eu desespero de ver que nessa Corte só aparecem factos mentirosos e a verdade se oculta, para que não seja socorrida a pobre Bahia, nas suas calamidades. Não, não, aqui não querem a independência. Aqui só desejam gozar dos privilégios de que aí se gozam. Os brasileiros não são enteados, são filhos. (vol. II, p. 127)

Pouco a pouco, o discurso apelativo assenta cada vez mais nas dicotomias entre o

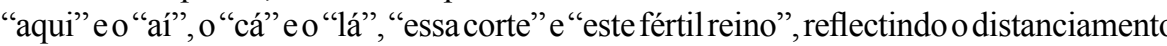
e a progressiva secessão entre Portugal e o Brasil que, de tão omnipresente no quotidiano, invade já o pensamento e a expressão individuais. Apesar do fervor com que defende a sua pátria de adopção, Maria Bárbara não faz a apologia da independência, nem hesita em exprimir profundo horror perante o desbaste das árvores e a ocupação da Igreja dos Aflitos pelas tropas sublevadas de D. Pedro (vol. II, p. 128), num curioso apontamento proto-ecológico. Numa perspectiva mais lata, também não se apercebe do quão próxima está a independência e de como é generalizada e violenta tal aspiração. ISSN 0034-9631 (Impreso) ISSN 2154-4794 (Electrónico)
Curiosamente, em carta ao pai, o primogénito afirma que Maria Bárbara é "uma Senhora e em nada se mete de políticas" (vol. II, p. 136). Na correspondência masculina entre os dois filhos varões e Luís Paulino, Maria Bárbara érelegada ao seu papel meramente familiar, ignorada ou reduzida a breve nota sobre a sua saúde e obstinação na recusa em abandonar Aramaré. Esta alternância entre omissão e condescendência resultará da incapacidade por parte dos filhos de avaliar as reais qualidades de Maria Bárbara (uma incapacidade em muito ditada pelo preconceito) e também do desconhecimento do seu elevado grau de cumplicidade com o marido. Ao que se associará a dificuldade em assumir perante a figura paterna que, na verdade, é ela a senhora do engenho, devido à incompetência que terão demonstado os "lavradores de Xangô" (vol. II, p. 63). Porque, na realidade, as cartas que Maria Bárbara escreve ao marido - sempre sigilosas e enviadas com grandes cuidados, por portadores de confiança - em nada diferem das dos filhos, nas temáticas e nos eventos narrados, delas se distanciando apenas na intensidade das lamentações e das expressões de ódio e afecto.

No final desta narrativa epistolar que as famílias Pinto da França e Garcez criaram involuntariamente, a independência do Brasil e a morte de Luís Paulino acabarão por dispersar os seus elementos. Maria Bárbara assume-se adepta da causa brasileira e permanecerá no Brasil até à morte, tal como o filho mais novo. Bento, o filho mais velho, manter-se-à fiel a Portugal, mas Sabina seguirá o marido, feroz independentista. Como feliz epílogo, permanece a descrição radiosa que Bertand Filipe Alberto Patron faz de Maria Bárbara, em A viagem de Patroni pelas Províncias Brasileiras de Ceará Rio de São Francisco, Bahia, Minas Gerais e Rio de Janeiro nos anos de 1829 e 1830 Seis anos volvidos sobre a morte de Luís Paulino, numa viuvez que irá durar vinte e oito anos, a senhora do engenho de Aramaré brilha ainda na sociedade baiana, reunida no engenho Brito de Iguape, entre Cachoeira e Santo Amaro:

Ilustre e muito bela viúva do Marechal Luís Paulino Pinto da França [...] A companhia era escolhida: todos os ricos lavradores de Iguape ali apareceram; reinava a profusão e a alegria por toda a parte; e a deusa a quem se dedicavam tantas oferendas fazia a alma daquele congresso respeitável. Eu lhe ouvi cantar uma breve ária, a doçura da sua voz encantou meus sentidos e fez em mim a mesma impressão que Vénus fizera ao pai dos deuses, quando as lácteas tetas the tremiam no concílio celeste, congregado para decidir da sorte dos lusitanos nos mares da Índia. (PATRONI, 1851)

Trânsitos, Traduções e Narrativas Interculturais: Teorias e Conclusões

A Correspondência Luso-Brasileira traça o itinerário de um constante movimento entre culturas, narrando a várias vozes um processo nem sempre bem sucedido de trânsito e adaptação intercultural. A necessidade de traduzir por palavras as práticas, valores e realidades de uma nova cultura - ou seja, de proceder a uma tradução intercultural - é

Revista Iberoamericana, Vol. LXXIX, Núms. 244-245, Julio-Diciembre 2013, 817-842 ISSN 0034-9631 (Impreso) ISSN 2154-4794 (Electrónico) 
mais evidente nas cartas trocadas entre os dois lados do Atlântico e nos comentários sobre a vida no Brasil, por comparação a Portugal. Esta representação polifónica de um movimento de transculturação pessoal, familiar, social e grupal, ao longo de quase duas décadas, funciona como uma tradução por vezes consecutiva, outras vezes simultânea, dos eventos vividos e testemunhados. Esta "tradução consecutiva e simultânea" tem um profundo valor documental, por não estar sujeita aos filtros da memória, algo que interfere sempre no processo das representações, pois lembrar não é ver, mas sim reconstruir as experiências do passado, com as imagens, ideias, juízos e valores do presente.

Juntamente com as autobiografias, as cartas e os diários compõem um subgénero que se poderá designar por "literatura do íntimo". As cartas pessoais, por serem manifestações por excelência do âmbito privado, têm a sua escrita associada à mulher, sobretudo em finais de setecentos e ao longo de todo o século XIX. Apesar de prevalecer a prática missivista anónima e quotidiana - característica que não a torna menos importante, tendo em conta os novos espaços de sociabilidade que as cartas constituem - a correspondência de muitas mulheres tem vindo a tornar-se uma fonte de estudo reconhecida, principalmente quando se trata de personagens influentes, com suas vastas teias de relações. Às mulheres em geral reservava-se a tarefa de manter os parentes distantes informados sobre o quotidiano familiar e de fazer circular as novidades mais recentes. Surge assim uma certa especialização feminina na tarefa de secretariar, mantendo em simultâneo os laços da vida da família. No caso de Maria Bárbara, o seu quotidiano doméstico incluia não só a vida familiar, mas também a supervisão da propriedade e o governo do engenho e seus escravos, num contexto muito distinto do das classes médias europeias em ascensão na Europa (GONÇALVES, 2006: 99 e segs.)

Sendo as cartas estruturas de comunicação informais, elas permitem que no seu conteúdo ocorra não só a narrativa das emergências, mas também a narrativa das ausências, adaptando aqui os conceitos que têm vindo a ser desenvolvidos por Boaventura de Sousa Santos (SANTOS, 2008: 11-43; SANTOS, 2006: 87-125). No caso presente, na Correspondência ocorrerá uma narrativa das emergências por nela se fazer ouvir a voz subalterna mas em ascensão da mulher, da colona, da burguesa, epitomizada na figura de Maria Bárbara. Mas encontra-se também aqui uma narrativa das ausências pois, para além das vozes emergentes, ou através (e por causa) dessas mesmas vozes, acede-se ainda à narração - de outro modo silenciada - da vida privada, do pessoal, do íntimo, do diálogo conjugal, do quotidiano da mulher emancipada dentro das estruturas sociais vigentes e aceitáveis. Este "relato da norma", esta "história da vida privada" num período histórico tão pouco normal e tão cheio de acontecimentos públicos, constitui um manancial de informação vital e complementar às histórias oficiais, uma informação tendencialmente ausente do cânone das grandes narrativas. Permite compreender a diversidade infinita da experiência humana e o risco que se corre de, com os limites de conhecimento e as exclusões impostas por cada saber, se desperdiçar experiência, isto é, de se considerar inexistentes ou impossíveis experiências culturais na verdade disponíveis (as "ausências") ou possíveis (as "emergências") (SANTOS, 2008: 33).

Adiversidade de práticas, conhecimentos, actrizes e actores resultantes dessa narrativa das ausências e das emergências pode, sem uma interpretação crítica cuidadosa, conduzir a uma pluralidade de narrativas e identidades encerradas sobre si mesmas, que ora se encontram ora se desencontram, sem que daí resulte nenhuma interacção construtiva. O trabalho de tradução será, por isso, a capacidade de pôr em relação, de comunicar, de criar inteligibilidade recíproca entre as experiências do mundo, encontrar pontos de convergência, e também pontos de divergência. É o que sucede nas cartas aqui analisadas que, a partir de uma visão eurocêntrica, introduzem novos elementos no quadro do quotidiano e movimentam-se no sentido da tradução intercultural. Partilham conceitos e mundividências alternativos, exprimindo-os de uma forma o mais compreensível possível para o leitor distante no espaço e no tempo. Existem contudo elementos que não podem ser traduzidos, razão pela qual se alude à incompreensão política entre a metrópole e o Brasil, à dicotomia entre o "aqui" e o "lá", à sátira ao Portugal rural por parte das damas já "brasileiras", entre tantos outros exemplos de incomunicabilidade. Mas esses hiatos na comunicação também são parte fundamental da tradução intercultural.

A tradução permite assim criar inteligibilidades recíprocas entre diversas experiências do mundo, tanto as disponíveis como as possíveis, reveladas por narrativas das ausências e por narrativas das emergências. No caso da Correspondência, pela multiplicidade das vozes nela registadas, o processo de tradução intercultural que ocorre não atribui a nenhum conjunto de experiências nem o estatuto de totalidade exclusiva nem o estatuto de parte homogénea. As experiências do mundo são vistas em momentos diferentes do trabalho de tradução como totalidades ou como partes, dado serem realidades que não se esgotam nessas totalidades ou partes. Permitem-nos também ver o subalterno tanto dentro como fora da relação de subalternidade, como no caso da figura paradigmática de Maria Bárbara, que tanto é hetero-representada como mãe de família quase privada de discurso autónomo, como se auto-representa enquanto senhora de engenho esclavagista, eloquente e autónoma. O conhecimento desta e de outras narrativas das ausências e das emergências aumentam extraordinariamente o número e a diversidade de experiências disponíveis e possíveis, dado que o trabalho de tradução cria inteligibilidade, coerência e articulação num mundo assim enriquecido por uma tal multiplicidade e diversidade (SANTOS, 2006: 114 e 119).

Maria Bárbara Garcez inicia o seu percurso entre culturas como simples espectadora e leitora passivamente fiel do seu papel social. A medida que o tempo passa - e movimentando-se sempre dentro dos estreitos limites permitidos pela norma - tornase progressivamente numa comentadora esclarecida, numa actriz autónoma, numa protagonista de carácter e, por fim, na autora do seu próprio papel, na sociedade, na política e na história. Um papel que desempenha com desenvoltura, apesar de (ou talvez
Revista Iberoamericana, Vol. LXXIX, Núms. 244-245, Julio-Diciembre 2013, 817-842 ISSN 0034-9631 (Impreso) 
por) ser um papel novo e quase desconhecido para ela própria e para a sociedade em geral. Pertencendo ao grupo dominado da sociedade senhorial, Maria Bárbara sabia como transitar dentro da lógica paternalista, conseguindo os seus objectivos sem, para isso, chocar com a ideologia dominante e utilizando frequentemente o discurso do dominador. Maria Bárbara evoluiu dentro das limitações impostas pelo cânone dominante e aproveitou a sua posição social privilegiada para construir a sua própria trajectória.

Para todos os intervenientes nesta correspondência, a narrativa da experiência pessoal contribui para conferir sentido e coerência às referências frequentemente aleatórias e caóticas que constituem a sua experiência do real. Por isso, ordenam a experiência ao enquadrá-la numa estrutura narrativa, porque contar ou escrever uma história envolve sempre interpretações, dado que seleccionar, de entre todo o conjunto de experiências vividas, os eventos e as personagens a enfatizar, é já por si um acto de interpretação. As narrativas pessoais nunca são simples reflexos da realidade vivida, são antes mediadas pela necessidade de representar o indivíduo como possuindo um certo sentido de identidade e de controlo, perante si próprio e os demais. Cada território fornece diferentes meios de mediar ideologicamente as vivências, personagens e acontecimentos. Mas quando o território espácio-temporal - como o território colonial ou o espaço-tempo da revolução e da independência - é ainda quase desconhecido, quando é ainda um espaço instável, de mobilidades várias, sem fronteiras culturais bem definidas, quando não existem mediadores ideológicos prévios, tudo tem de ser reorganizado, re-apresentado, traduzido num código inteligível.

O Brasil pré- e pós-colonial funciona assim como uma zona de contacto, usando de novo a terminologia de Boaventura Sousa Santos, uma zona de fronteira, onde as periferias e as margens dos saberes e das práticas são as primeiras a emergir. Só o aprofundamento do trabalho de tradução permite ir trazendo para a zona de contacto os aspectos que cada saber ou prática considera mais centrais ou relevantes (SANTOS 2006: 121). O espaço físico, a identidade e o discurso interseccionam-se e influenciamse mutuamente e os diferentes espaços e territórios frequentados ou representados em imagens e narrativas são experimentados e compreendidos das mais diversas maneiras. Para Michel de Certeau, o espaço é activado pelas práticas retóricas daqueles que o frequentam e as opções semióticas e enunciativas do viajante privilegiam, transformam e omitem elementos espaciais, de modo a fazê-los significar algo ou, pelo contrário, coisa nenhuma (CERTEAU, 1988 [1984]: 196-8).

Assim, nas zonas de contacto intercultural, cabe a cada prática cultural decidir os aspectos que devem ser seleccionados para tradução. Em cada cultura há aspectos considerados demasiado centrais para poderem ser postos em risco pelo confronto que a zona de contacto pode representar, ou aspectos que se considera serem inerentemente intraduzíveis noutra cultura. Exemplo disso, e tema fulcral neste estudo da Correspondência Luso-Brasileira, será a libertação da mulher do seu estado de opressão - premissa base para a manutenção da sociedade patriarcal -, um aspecto que

Revista Iberoamericana, Vol. LXXIX, Núms. 244-245, Julio-Diciembre 2013, $817-842$ ISSN 0034-9631 (Impreso) ISSN 2154-4794 (Electrónico) poderia ser até propiciado pelas circunstâncias históricas extraordinárias em curso na zona de contacto Brasil, mas que a cultura dominante jamais coloca em risco. A questão do que é ou não traduzível não se limita ao critério de selectividade que cada prática ou saber decide adoptar na zona de contacto. Para além da selectividade activa, há o que poderiamos designar a selectividade passiva. Esta consiste naquilo que numa dada cultura se tornou impronunciável devido à opressão extrema de que foi vítima durante longos períodos. Trata-se de ausências profundas, de vazios sem possibilidade de preenchimento, vazios que dão forma à identidade imprescrutável dos saberes e práticas em questão (SANTOS, 2006: 121). Na Correspondência, trata-se sem qualquer dúvida da questão da escravatura. $O$ grande ausente, o grande silenciado é aquele que, contudo, sustenta toda a estrutura do engenho, da economia e da sociedade: o escravo.

No caso desta Correspondência, há um claro domínio dos temas ligados à intriga política e familiar, ao dinheiro, à ascensão social, como se as práticas e valores da província portuguesa tivessem sido transportados incólumes para o novo território brasileiro. $\mathrm{O}$ Brasil, espaço imenso, tão diferente e exótico, emerge nas descrições do engenho, da vegetação, do clima, do luxo, da indolência, mas transformado em simples adjuvante ou oponente na narrativa omnipresente do enriquecimento e da promoção social. As zonas de contacto assim criadas nunca são verdadeiramente híbridas. Tudo aquilo que não se enquadra nesta grande narrativa subjacente, guia de todos os trânsitos entre Portugal e o Brasil, é simplesmente omitido, pois não tem qualquer significado para os actores em cena. Todos os processos de silenciamento e produção de não-existência que ocorrem nestas cartas - como o silenciamento das mulheres na correspondência masculina; o silenciamento dos escravos em toda a correspondência; os processos culturais sem palavras que os reconheçam ou nomeiem - contribuem para a construção e fortalecimento das assimetrias na relação entre culturas, indivíduos, sociedades e géneros, próprias do colonialismo e do patriarcado. Porque, e citando de novo Boaventura de Sousa Santos, "as culturas só são monolíticas quando vistas de fora ou de longe. Quando vistas de dentro ou de perto é fácil ver que são constituídas por várias e por vezes conflituais versões da mesma cultura" (SANTOS, 2006: 121).

No momento da escrita da carta, está em jogo não só a conservação das memórias familiares, mas também a identidade individual e social do seu autor. As memórias são construídas por grupos sociais porque, apesar de serem os indivíduos que "lembram" no sentido literal da palavra, são os grupos sociais que determinam o que é ou não "memorável" e também a forma como algo será recordado (BURKE, 2000: 70) Pode-se, portanto, afirmar que a memória é um elemento constituinte do sentimento de identidade, tanto individual como colectiva, na medida em que ela é também um factor basilar do sentimento de continuidade, coerência e auto-(re)construção de um indivíduo ou de um grupo. A maior contribuição destas cartas não estará tanto na sua credibilidade como documento, no sentido positivista, pois, tal como afirma Sidney Chalhoub a propósito da ficção literária, esta "busca a realidade, interpreta e enuncia

Revista Iberoamericana, Vol. LXXIX, Núms. 244-245, Julio-Diciembre 2013, 817-842 ISSN 0034-9631 (Impreso) ISSN 2154-4794 (Electrónico) 
verdades sobre a sociedade, sem que para isso deva ser a transparência ou o espelho da 'matéria' social que representa e sobre a qual interfere" (CHALHOUB, 2003: 92). A interpretação aqui feita da Correspondência Luso-Brasileira busca, isso sim, sentidos mais complexos, ao analisar criticamente os discursos que regem a lógica da narrativa intercultural e as práticas que movem as representações do real.

\section{REFERÊNCIAS}

Bittencourt, Maria Clara Mariani (org.), Obras de Anna Ribeiro de Araújo de Góes: Longos Serões do Campo, vol. 2. Rio de Janeiro: Nova Fronteira, 1992.

Bourdieu, Pierre. Razões Práticas sobre a Teoria da Acção. Miguel Serras Pereira, trad. Oeiras: Celta Editora, 1997 [1994].

Boxer, Charles. A Mulher na Expansão Ultramarina Ibérica. Lisboa: Livros Horizonte, 1977.

Burke, Peter. Variedades de História Cultural. Rio de Janeiro: Civilização Brasileira, 2000. Cardoso, António Manuel Monteiro; António d'Oliveira Pinto da França (eds.). Correspondência Luso-Brasileira. 2 vols. Lisboa: Imprensa Nacional Casa da Moeda, 2008.

Certeau, Michel de. The Practice of Everyday Life, trad. Steven Rendall. Berkeley: U of California P, 1988 [1984].

Chalhoub, Sidney. Machado de Assis Historiador. São Paulo: Companhia das Letras, 2003. Godinho, Tereza Martins. "Traços da Violência Praticada por Mulheres Brancas contra Mulheres Negras no Período Escravocrata, em Fazendas no Estado de Goiás". Actas do Seminário Internacional Fazendo Gênero, $\mathrm{n}^{\circ}$ 7. Florianópolis: Agosto de 2006. Gonçalves, Andréa Lisly. História \& Gênero. Belo Horizonte: Autêntica, 2006.

Mattoso, Kátia M. de Queirós. “A opulência na província da Bahia”. História Privada do Brasil, vol. II. Luis Felipe de Alencastro, ed. São Paulo: Companhia das Letras, 1997. Mattoso, Kátia. Família e sociedade na Bahia do século XIX. São Paulo: Corrupio, 1988. Patroni, Bertand Filipe Alberto. A viagem de Patroni pelas Provincias Brasileiras de Ceará, Rio de São Francisco, Bahia, Minas Gerais e Rio de Janeiro nos anos de 1829 e 1830. Lisboa: 1851.

Priore, Mary del y Rentao Venâncio. Uma História da Vida Rural no Brasil. Rio de Janeiro: Ediouro, 2006.

Santos, Boaventura de Sousa. "A Filosofia à Venda, a Douta Ignorância e a Aposta de Pascal". Revista Crítica de Ciências Sociais 80 (Março 2008): 11-43. A Gramática do Tempo: Para uma Nova Cultura Política. Porto: Afrontamento, 2006.

Silva, M. J. Quilombo do Brasil Central: Violência e Resistência Escrava 1719-1888. Goiânia: Kelps, 2003.

Revista Iberoamericana, Vol. LXXIX, Núms. 244-245, Julio-Diciembre 2013, 817-842 ISSN 0034-9631 (Impreso) 